Fiscal policy response to cycles under two regimes: Spain 1950-1998

October 2012

\begin{abstract}
In the second half of the $20^{\text {th }}$ century Spain provides a case of political regime change which according to some political economy models should also lead to a shift in the cyclical nature of fiscal policy. We find that in most of the pre-democratic era there was a strong pro-cyclical bias to fiscal policy. Eradication began in the last years of the autocratic regime under the influence of fiscal institutional reform and perhaps learning. It was completed after the transition to democracy when counter-cyclical fiscal policy was reinforced in the late 1980s by membership of the European Exchange Rate Mechanism. This experience, established by two separate econometric identification procedures, as well as a narrative drawing especially upon OECD and EIU reports, runs counter to the predictions of the political economy models of Lane (2003) and Alesina et al (2008).
\end{abstract}

JEL Codes: E32, E62, N14

Keywords: fiscal policy, business cycle, regime change 


\section{Fiscal policy response to cycles under two regimes: Spain 1950-1998*}

It is a commonplace that economic policy was a critical influence on fluctuations in western European output and employment in the 60 years after the Second World War (Maddison 1991 p172; Battilossi et al 2010). In particular Boltho and Toniolo (1999) maintain that the error of pro-cyclical fiscal policies in the 1930s was rarely repeated by developed countries in the second half of the century. Raising government spending, and/or cutting taxes during an upswing in economic activity as this would entail, exacerbates output volatility, magnifying the impact of booms, recessions and crises (Gavin et al. 1996). As debt accumulates, 'fiscal consolidation' may become necessary for long term sustainability (the state's ability to continue debt service and borrowing). Running excessive budget deficits in a boom eventually would need to be corrected in a recession.

Optimal fiscal policy prescribed by Keynesians instead is counter-cyclical, while new classical thought recommends a-cyclicality. Yet an early study of the management of the British economy between 1945 and 1960 concluded that fiscal policy amplified, rather than mitigated, fluctuations in the growth of demand (Dow 1964). Lundberg's (1968) assessment of policy in six OECD countries did not find fiscal policy to be counter-cyclical or even acyclical in the 1950s. More government spending in the US could have eliminated the deficient demand gap in 1956-7 and 1960 but did not (Lundberg 1968 p375), while Dutch fiscal policy was procyclical in the 1955-56 boom and the recession of 1958-9 (Lundberg 1968 p287). Later, in the period 1970-94, fiscal policy in the G7 countries appeared to be acyclical while fiscal policy in developing countries was undoubtedly pro-cyclical (Talvi and Vegh 2005).

\footnotetext{
* The authors are grateful for their useful comments and suggestions to anonymous referees and to participants in the Third Iberometrics Conference (Valencia), the European Historical Economics Society Conference (Lund), the XVIII Meeting of Public Economics (Malaga), where previous drafts of this research were presented. Battilossi acknowledges the financial support of the Spanish MICINN through projects ECO2008-02089 and ECO2011-25713, and the generous hospitality of the Department of Economic History at the LSE, where he spent a semester in 2010 as a Senior Visiting Fellow. Escario acknowledges financial support from the Spanish MICINN through project ECO2009-08204, the "Programa Europa XXI para estancias de investigación del Gobierno de Aragón y la Caja Inmaculada", and Grupo de Excelencia de Investigación SEIM (SEC 269-124). The usual disclaimer of responsibility for remaining errors and omissions applies.
} 
This divergence between the ideal and actuality may have stemmed from Keynes' legacy to economic policy. Keynes assumed that policy will be conducted by benevolent policymakers, advised by competent and incorruptible civil servants. If this assumption is incorrect the divergence might be explained (Friedman 1997). Recent accounts of pro-cyclical fiscal policy take this line and focus on political economy. Procyclicality can be triggered by opportunistic political budget cycles in which incumbents facing competitive elections attempt to increase their chances of being reelected by boosting spending in election years. Particularly when institutional constraints are weak or non-existent this behaviour may be expected (Diallo 2009).

Governments may be induced to overspend during booms by voters' demands in corrupted political systems (Alesina et al. 2008). Political fragmentation, lack of democratic participation and more generally the absence of "institutions for conflict management" (Rodrik 1999) may also intensify lobbying and the struggle between "voracious" political units or interest groups for the appropriation of growing fiscal revenues (Lane and Tornell 1996; Tornell and Lane 1999; Lane 2003). The incentive for any pressure group to act prudently is low when each knows that refraining from increasing its demands during expansions will not allow the government to run a budget surplus; rather, other groups will further increase their appropriations. Politically motivated pro-cyclical fiscal policies are more likely to be observed in "new" democracies where governments use budget policies to consolidate fragile democratic institutions (Brender and Drazen 2005 and 2007).

Little of this research has been concerned with the whole period since the Second World War, during which national political institutions and economic policies may have changed and there were opportunities for learning (Bajo-Rubio et al 2010 is an exception). Instead typically national policy reaction functions are assumed fixed over the period of analysis. A more historical approach can offer some understanding of the reasons for cyclicality of fiscal policy, particularly with the study of transitions, for which Spain is a prominent case. Moreover, recent studies (Escario et al. 2011, 2012) provide empirical support for the now widely accepted view of Spanish economists and policymakers that fiscal dominance (a policy stance in which fiscal deficits determine the path of money creation) prevailed for most of the period. Dominance was not clearly abandoned until the 1990s, when the Bank of Spain gained formal independence. With 
Spain's entry to the EMU in 1998, a new era in fiscal policy implementation began. On the one hand, the transfer of monetary autonomy to the European Central Bank and the acceptance of the Stability and Growth Pact restrictions on deficit and debt figures imposed a de facto limitation on government leeway for pro- or counter-cyclical fiscal responses. On the other, long term interest rates fell to less than half of their previous average. For both these reasons 1998 is a suitable year in which to end the analysis.

A focus on the Spanish transition allows a test of Lane's (2003) hypothesis that the more power is diffused among a number of agents/institutions, the higher is fiscal procyclicality relative to that of a unitary system. Lane uses the Henisz (2000) index based on the number of independent branches of government with veto power, to measure the benefits of constraints on the executive. This index is zero for the Soviet Union from 1960 and also for Spain from 1960 to 1975 . Thereafter the Spanish index jumps to a level broadly comparable with that for the UK. On the Lane hypothesis (and the Heinisz index) Spain should have seen a marked increase in fiscal pro-cyclicality after 1976.

With a different model and political index Alesina et al (2008) reach a similar conclusion. For these researchers, pressure group politics ensures that the combination of democracy and corruption is the key to fiscal pro-cyclicality. The Alesina et al study uses the Polity IV index of democracy-autocracy that measures regime authority on a 21-point scale ranging from -10 (hereditary monarchy) to +10 (consolidated democracy). The Spanish index is -7 before 1976, jumping to +9 followed by +10 from around 1990. With an unchanged level of corruption, again this model predicts an increase in Spanish fiscal pro-cyclicality after the transition.

Yet some studies suggest that after the Spanish transition fiscal policy stabilized private consumption and output growth (was counter-cyclical), mainly thanks to the expansion of welfare provisions and the increasing size of the public sector (Dolado et al. 1993, Gómez 1993, Marín 1997). Fatas and Mihov (2009) also find that cyclically-adjusted spending was countercyclical, contrary to the predictions of the Alesina et al and Lane models, while De Castro and Hernandez De Cos (2008) conclude that the stance of Spanish fiscal policy became more counter-cyclical from the mid 90 s.

By contrast Bajo-Rubio et al (2010) judged that there was no evidence of structural breaks in Spanish fiscal policy over 150 years; throughout, fiscal authorities only took 
action when deficits exceeded about 4.5\% of GDP. Daban et al (2003) observed that between 1980 and 1991 Spain, like France, Germany and Italy, pursued on average a pro-cyclical policy. ${ }^{1}$ Also Spanish unemployment spending was positively correlated with the output gap between 1980 and 2000 (was pro-cyclical, as structural unemployment increased). It is fair to conclude therefore that the evidence warrants a more detailed examination of the cyclical nature of Spanish fiscal policy on either side of the transition before a conclusion can be reached about the particular contribution of political regimes to this aspect of policy.

This is the main objective of the present paper; to assess whether and how, if at all, the transition from autocracy to democracy impacted on the fiscal response to fluctuations in economic activity. To ensure the robustness of our conclusions we use two different approaches to test for shifts in fiscal cyclical stance. As support for the econometrics and to set the scene we provide a narrative of the cyclical behaviour of fiscal policy in Spain across political regimes.

The paper is structured as follows. In section 1 we outline the institutional background and the cyclical patterns of fiscal policy under autocracy and democracy. In section 2, we explain in general terms how we model fiscal reaction functions. Estimation is described in section 3, first with a structural VAR and then as an alternative, to ensure the robustness of our findings, with instrumental variables (IV). The IV approach also allows us to test possible institutional determinants of the observed shifts in fiscal policy stance. Section 4 concludes.

\section{Narrative}

In this section we employ the 'narrative method' (Romer and Romer 1989), analysing the historical record of the processes and the reasoning behind fiscal decisions, to identify the cyclicality of fiscal behaviour. We use contemporary political and economic analyses, as published in the OECD Economic Surveys and the Quarterly Economic Reviews of The Economist's Intelligence Unit, to outline the institutions, objectives and instruments of fiscal policy in Spain across political regimes and over time. The view of

\footnotetext{
${ }^{1}$ Measured by the proportion of years for which the output gap and the 'fiscal impulse' -the improvement in the structural balance- have opposite signs.
} 
external independent observers is especially valuable as it is less contaminated by the political discourse that governments used to "sell" their policies to public opinion. Moreover, since the late 1950s the OECD gained an intimate knowledge of Spanish economic policy-making by assisting the government in its plans for macroeconomic stabilization and gradual liberalization. To anticipate the results of our qualitative examination, foreign analysts identified pro-cyclicality as one of the main problems of Spanish fiscal policy until the mid 1960s. Their analysis also suggests that this procyclical bias became less pronounced during the last period of the autocratic regime and the political transition of the 1970s, and was eventually defeated by democratic governments.

Spain began the period with a fiscal regime characterized by small government, a low but regressive tax burden and low spending heavily biased towards government consumption. At the end Spain had moved to big government, with a progressive but consistently increasing tax burden and high spending, largely oriented towards subsidies and welfare schemes. Figure 1 shows the course of central government's budget, together with some components of spending, and tax receipts. Not included is spending by a variety of public bodies and administrations such as INI or debt service (Argimón et al. 1999, p.52). ${ }^{2}$ Between the tax reform of 1957 and the social security reform a decade later, central government spending (excluding social security spending, debt service and spending on state enterprises such as INI) rose from around 8 percent of GDP to 12 percent. Social security spending as a proportion of GDP doubled between 1966 and 1976 and continued to grow thereafter. The transition to democracy, between 1976 and 1982, saw central government spending leap upwards from 12 to 20 percent of GDP, while tax receipts rose with a lag less strongly to around 17 percent of GDP.

Economic policy in the autocratic period was shaped by the interaction of the Falangist party of government favouring a closed and heavily regulated economy, and a group of Europe-minded technocrats who tried to combine indicative planning with marketoriented reforms, the opening of the economy and a Keynesian approach to economic policy (Encarnación 1997; Prados de la Escosura et al. 2011). Unfortunately, fiscal policy was poorly instrumented and coordinated. The practices of revenue budgeting

\footnotetext{
${ }^{2}$ A World Bank mission in 1962 identified over 1,600 autonomous official spending units with less than adequate reporting standards, and was obliged to confine their discussion of Spanish public expenditure to central government spending, the only category for which they could obtain data (World Bank 1963).
} 
and biannual budgets, which were meant to impose controls on bureaucracies, made spending decisions inflexible and survived until 1971, when the government adopted annual budgeting. At the same time they did not allow effective control, since the systematic use of supplementary and extraordinary expenditures made actual spending systematically diverge from officially announced targets (OECD, January 1970, pp. 50$52)$.

In spite of exchange controls and pervasive price regulation, Spanish inflation in the first phase was high and erratic. Because of the massive inflation jump to 18 and 15 percent in 1950 and 1951 respectively (the Korean War terms of trade shock), the rise in output per head in 1951 above 1947 level was insufficient to prevent strikes in Barcelona and related Cabinet changes. When inflationary pressure due to supply side shocks seemed to subside, in 1953, a new crisis hit the economy: total output fell slightly (-0.3 percent), although industrial production did not. With expansionary fiscal and monetary policy in 1954-55, soon after the recovery once more inflationary pressures picked up.

The boom initiated in 1955 triggered mounting pressure by official syndicates/trade unions, supported by the Falangist party, for a 'more equitable distribution of national income', with repeated waves of strikes (EIU, n. 19, September 1956). In response the regime decreed a 20 per cent increase in nominal wages in the public and private sectors and expanded public investment, while INI (where the Falangists were also influential) launched a massive investment plan entirely funded by public debt (Schwartz and González 1978, pp. 81-82). Pro-cyclical government spending is clear in these years.

Fiscal expansion continued in 1958 when annual inflation reached 12 per cent (EIU, Annual Supplement, July 1959). By early 1959 domestic and external imbalances had virtually eliminated foreign exchange reserves, leading to a 20 per cent devaluation of the Peseta and the request for international assistance (Carreras and Tafunell 2004, pp. 319-24). The stabilization of the economy, enforced by the liberal technocrats under the supervision of the OECD, dictated a strong fiscal adjustment to eliminate excess internal demand, which exacerbated the ongoing recession (OECD, August 1960, p. 20).

During the expansion of 1961-66, which culminated in the strong capital inflows of 1965-66 (Reinhart and Reinhart 2008), rapid (pro-cyclical) growth of public sector 
expenditures, especially in the housing sector, was identified by international observers as a critical component of excess domestic demand. Nominal annual growth of total public spending peaked at over 20 per cent in 1964-65, with investment and capital transfers accounting for one third (OECD, July 1966, pp. 15-23; Beltrán and Oliart,1967, pp. 69-70). Inflation, back again to 12 per cent in 1965, could be kept under control in 1966-67 only by a credit squeeze based on quantitative constraints imposed by the Bank of Spain, controlled by the liberal technocrats (EIU, n. 3, August 1966).

Pressed hard by the OECD and the domestic business community, the government eventually announced an austerity package-including cuts in spending, a tax hike on profits and luxury consumption, and a freezing of wages and prices - at the same time as the Peseta devaluation of November 1967, at the cost of accelerating the slowdown in private investment (EIU, n. 3, August 1967, and n. 4, December 1967; OECD, January 1969, pp. 16-18). In these episodes pro-cyclical public spending is easily recognized.

A different pattern emerged in the late 1960s. According to OECD observers, fiscal procyclicality began to decline in the final period of the pre-democratic regime. As figure 1 shows, with primary spending/GDP stable and tax revenues rising, fiscal discipline was maintained during the 1969-70 expansion in order to prevent overheating of the economy. This policy succeeded in moderating demand growth, contributing to the reversal of both a mounting current account deficit and expectations of a new devaluation of the peseta (OECD, January 1971, pp. 5-15).

When economic activity slowed in 1971, the government switched to reflationary measures, including a massive increase in state spending on social security, more public investment, greater transfers to official credit institutions and tax rebates on private investment, with an explicit countercyclical objective (EIU, n. 3, August 1971; OECD, January 1972, p. 14; Canseco 1978; Argimón et al. 1999, p. 55). The fiscal stance in 1973-74 remained expansionary, with tax cuts on production and increasing subsidies to firms, in response to a slowdown in economic activity, aggravated by the reversal in expectations caused by the first oil shock (Argimón et al. 1999, p. 63). This countercyclical action was estimated largely to have offset the contractionary pressure from the international crisis (Galy et al. 1993, p. 4), although at the cost of further fuelling inflation. 
During the political transition of the mid 1970s and the early years of the democratic regime, state welfare provision increased. By the mid 1980s central government and social security budgets combined had jumped close to 35 per cent of GDP. As spending systematically outpaced tax revenues, fiscal policy boosted public debt from 12 to 44 per cent of GDP between 1975 and 1985.

The rapid transition to big government took place in adverse macroeconomic conditions of low growth and high inflation. Government's commitment to fiscal reforms was a key element of the Moncloa Pacts of 1977, negotiated by all political parties represented in the newly elected Parliament, and the subsequent coordination agreements signed by the government, employers' organizations and trade unions (Royo 2001). This new framework was intended to regulate social bargaining and coordinate monetary, fiscal and income policies. Inflation reached a record 22 per cent in the year of the Pact and fell to single digits only in 1985. Economic growth slowed to an average of 2 per cent between 1977 and 1985 and unemployment escalated to 18 per cent in the same period. Claims by trade unions were satisfied by expanding social protection, especially retirement and unemployment benefits. The government also accompanied the restructuring of an obsolete industrial sector with a generous expansion of subsidies to private and public companies (Argimón et al. 1999, pp. 63-64; González Páramo 1990; Valle 1990). A counter-cyclical policy temporarily sacrificed fiscal responsibility to the consolidation of democracy in a stagnating economy.

Reforms increased the automatic stabilizing properties of the budget and gave fiscal policy more flexibility. The 1977 budget act introduced three fundamental innovations in fiscal policy: consolidated and refined accounts for the public sector, better coordination of investment by state-owned bodies with the government budget, and forecasting models of tax revenue (Canseco 1978, pp. 197-203). Controls on public spending focused on procedural correctness, and evaluation. Policy planning followed in the early 1980s, when budgets by programmes were adopted (Zapico Goñi 1988). The 1977-78 tax reform introduced a progressive income tax for individuals and companies. Although the modernization of the tax administration and the struggle to reduce tax frauds were initiated by the governments of 1979-82, they gained momentum after the Socialist victory in the 1982 elections. Reform of indirect taxation was delayed by resistance of business organizations and the introduction of a value added tax was 
achieved only in 1986 (Fuentes Quintana 1990, pp. 478-502; Comín 2007, pp. 24-40; for an overview, Martínez Vázquez and Sanz-Sanz 2007).

The almost uninterrupted fiscal expansion of the decade 1975-84 moved countercyclically to the long stagnation of the Spanish economy. In this period the contraction of private investment and the depression of domestic demand pushed unemployment from 8.6 percent in 1979 to 21.5 percent in 1985 (Vázquez 1990). The stimulus provided by the public sector was intended partially to offset the impact on activity and employment of an increasingly restrictive monetary policy aimed at disinflating the economy (OECD, April 1979, pp. 20-21, and May 1981, pp. 19-20).

After 1984 continuing fiscal expansion and economic recovery proved incompatible with the sustainability of the peg of the Peseta to the DM - a key factor in macroeconomic stabilization and a priority for the Spanish government. ${ }^{3}$ The switch to a (counter-cyclical) tight fiscal policy with the start of economic recovery, together with the refusal to agree on nominal wage increases requested by the unions, led to a crisis of national-level coordination (Royo 2000). Spending subsided and the tax burden increased thanks to the introduction of VAT and marginal reforms of income taxation, reversing the trend of the government's deficit. Official pegging of the Peseta to the Deutschmark within the Exchange Rate Mechanism of the EMS (within a wide fluctuation band of 6 per cent) was achieved in 1989, and successfully maintained in the following two years, allowing Spain to sign the Maastricht Treaty at the end of 1991. Capital liberalization was part of the package, but what made a difference was fiscal adjustment and economic policy coordination.

Nonetheless reforms had permanently installed a larger non-discretionary component of fiscal policy, due to retirement pensions, health spending and unemployment benefits. Moreover, buoyant growth triggered the mobilization of labour unions (exemplified by the general strike of 1988), which obtained a further permanent expansion of welfare schemes and a slight decrease of income tax rates from the ruling Socialist government

\footnotetext{
${ }^{3}$ In fact, after the emergency devaluations of 1976 and 1977, the Spanish governments showed a persistent 'fear of floating'. Reinhart and Rogoff (2004) classify the Peseta exchange rate as a de facto 2\% crawling band around the Deutschmark from 1980 to 1994. Ledesma et al. (2005) also find that a de facto peg to the Deutschmark prevailed between 1978 and 1984, and again between 1986 and the 1993 crisis, and was temporarily abandoned only in 1985 in response to speculative attacks in the wake of Spain's accession to the EEC. These results strongly suggest that Spanish monetary authorities worried about the pass-through from exchange rates to prices and systematically intervened to smooth fluctuations in the nominal exchange rate, even in the absence of a formal commitment to peg.
} 
(Gómez and Roldán 1995). These measures, however, became operative during the subsequent slowdown in economic activity, which culminated in the generalized European recession of 1991-93 turning a pro-cyclical fiscal decision into a countercyclical measure that increased pressure on the budget. Emergency tax increases failed to put the brakes on the deficit, approaching 10 per cent in 1993, and the debt/GDP ratio rose above 60 per cent (Argimón et al. 1999, pp. 76-86). Deteriorating fundamentals, violating both the deficit ( 3 per cent) and debt thresholds (60 per cent) set by the Maastricht Treaty as a condition for admission to the last phase of monetary unification, triggered speculative attacks that forced three devaluations of the Peseta in 1992-93.

The subsequent revision of convergence plans failed to discipline fiscal policy, which achieved a new peak of the deficit at 8.6 per cent in 1995. A reform of fiscal institutions that guaranteed a more effective, centralized discipline in budget execution (such as the creation of a budget office reporting directly to the prime minister), together with extraordinary revenues from privatizations of public companies, cuts in subsidies and welfare schemes, and the revenues generated by a new cyclical expansion of the economy, were critical for the success of the fiscal adjustment that allowed Spain to adopt the single currency in 1998 (Argimón et al. 1999, pp. 86-94). Even so, the episode of the early 1990s raises a question over whether the pro-cyclical bias in fiscal policymaking had been entirely eradicated by the date of Spain's entry into the EMU, the end of our study.

The 'irrevocable' entry into the eurozone radically changed the policy options and the policy challenges. The euro imposed its own limiting rules on deficits and, in any case, the monetary financing of fiscal overspending - which had been a traditional means to cope with budget imbalances - was no longer an option. The possibilities for national fiscal policy manoeuvres were henceforth restricted to obtaining credit from international financial markets and, eventually, to an increasing supra-national surveillance. Thus, 1998 emerges as a natural end point for a study on national fiscal policy responses to cycles.

\section{Modelling the fiscal reaction function}


Does more formal modelling support this narrative? Three elements of fiscal policy can be distinguished: a cyclical, non-discretionary component, determined by automatic stabilizers such as tax revenues (pro-cyclical) or unemployment benefits (countercyclical); a discretionary, systematic component, that is, deliberate and systematic responses of the government to the state of the economy; and $a$ discretionary, non-systematic component, that is, budget decisions not related to economic fluctuations.

The cyclical non-discretionary component depends on structural features of the fiscal regime, such as the size of the public sector and the composition of tax receipts and expenditures. Big government, a progressive tax system and large spending on unemployment benefits and other subsidies related to economic fluctuations, exhibit greater stabilizing properties than regimes with regressive taxation and spending concentrated on government consumption (Andrés et al. 2007; Fatás and Mihov 2001; Galí 1994; van de Noord et al. 2000). ${ }^{4}$

The second element, systematic discretionary responses to cyclical fluctuations, can be modelled as "reaction functions" (Fatás and Mihov 2003, Galí and Perotti 2003). The third element (non-systematic discretionary) are "fiscal shocks", that is, changes in the fiscal stance that are exogenous to the economy and to built-in characteristics of the tax and spending process.

Our focus in this paper is on "reaction functions". Denoting $g$ as an indicator of the change in fiscal stance and $y$ as an indicator of changing economic conditions (say, output growth), the systematic discretionary component is measured by the parameter $\mathrm{c}$ in the reaction function

$$
g=\mathrm{c}\left(y-y^{*}\right)+u_{g}
$$

where $y^{*}$ is a target output growth and $y$ is the realized (or expected) growth. Fiscal shocks are represented by $u_{g}$; their dispersion measures the aggressiveness of idiosyncratic or non-systematic changes in fiscal policy (Fatás and Mihov 2008). Assuming standard Keynesian effects, fiscal policy affects the economy through an impact equation, where $u_{y}$ represents output or supply shocks;

\footnotetext{
${ }^{4}$ Recent studies suggest that the stabilizing effect of government size may have significantly declined since the 1980s (Mohanty and Zampolli 2009). The latter evidence is consistent with the decline of fiscal multipliers observed by Perotti (2005).
} 


$$
y=\mathrm{b}(g)+u_{y}
$$

Substituting (1) into (2), discretionary fiscal policy is counter-cyclical when $c<0$. When c $>0$, fiscal policy is pro-cyclical, as aggregate demand growth is reinforced by government expenditure and policy exacerbates cyclical fluctuations.

If Ricardian equivalence held there would be an inverse cycle in private consumption in the event of cyclical government spending and no change in aggregate demand (equation 2 would be redundant). In the more plausible case of credit-constrained consumers and imperfect information equation 2 will capture fluctuations in aggregate demand and output. ${ }^{5}$

While government infrastructure spending may increase long run output, military expenditure by the state is likely to do the reverse (for example Chang et al 2011). In both cases there is an opportunity cost in terms of private goods, for in the long run sustainable government spending must be financed by taxation. Because we are here concerned with the business cycle, as a simplification we assume that the positive and negative impacts offset each other so that government spending in aggregate had no long run positive or negative effect on real output. ${ }^{6}$ When taxation is introduced explicitly similar considerations apply as for expenditure.

A critical choice for our empirical analysis is the indicator of fiscal stance. A popular measure is the cyclically adjusted GDP ratio of the primary balance, which identifies fiscal rules and shocks by eliminating the fully endogenous component of fiscal policy (Galí and Perotti 2003; Fatás and Mihov 2009). ${ }^{7}$ However, Kaminsky et al. (2004, pp. 7-9) demonstrate that the cyclicality of fiscal policy cannot be assessed unambiguously whenever the real primary balance or its GDP ratio are used. ${ }^{8}$ As a consequence, an

\footnotetext{
${ }^{5}$ There has been some theorising about the effects of fiscal policy shocks under normative fiscal rules (summarised by Daban et al 2003) but the reaction functions investigated here are not announced rules.

${ }^{6}$ Also a common finding of empirical economic growth models is that government consumption has a negative impact whereas education, often largely financed by the state has a positive impact. For example in Barro (1997) these two effect virtually offset each other.

${ }^{7}$ However, estimates of potential or trend output, as well as the systematic distortions introduced by estimated tax and spending elasticities in the cyclically-adjusted balances are also controversial issues (Alberola et al. 2003: Mohr and Morris 2007).

${ }^{8}$ In the case of acyclical fiscal policy with constant tax rate and government expenditure, tax revenues and the primary balance are positively correlated with the cycle, but the GDP ratio of government expenditure is negatively correlated with the cycle, and the correlation of the GDP ratio of tax revenues is ambiguous, as it also turns the GDP ratio of primary balance. With procyclical fiscal policy (identified by falling tax rate and increasing expenditure in good times), the correlation of tax revenues and their GDP
} 
increasing number of studies contend that only pure 'instruments' of fiscal policy, such as real spending, are able to capture the fiscal stance of the government and to discriminate between pro-cyclical (magnifying), countercyclical (stabilising) and acyclical policies (Lane 2003; Fatás and Mihov 2008; Ilzetzki and Végh 2008).

Following this literature, we use the growth rate of $(\log )$ real primary spending of the central government net of social security expenditures as our indicator of the fiscal stance of the government. The exclusion of interest payments and social spending (including unemployment benefits) guarantees that, whatever reaction function we might observe, this measure will depend on discretionary systematic responses, not on automatic stabilizers. To ensure the reliability of our conclusions we will look also at the cyclical behaviour of aggregate spending including social expenditures, as well as of different components of government spending.

Our main indicator of the state of the economy is an industrial production index. A particularly useful characteristic of industrial output is that, unlike real GDP, the official estimates of which became available only in the early 1960s at annual frequency, it was observable both at annual and quarterly frequency by contemporary economic and political actors from the 1950s. ${ }^{9}$ We also check these results against estimates based on annual GDP data. (See Appendix for details on data and sources).

\section{Two approaches to estimating changing fiscal reaction functions}

In this section we investigate the cyclical properties of Spanish fiscal policy in order to uncover possible transitions in the government's response to the growth process. We estimate fiscal reaction functions first with structural VARs. Then we use an instrumental variables approach to strengthen confidence in our results and to explore the most likely determinants of shifts in fiscal responses.

ratio with the cycle is ambiguous (the tax rate falls but the tax base increases) and the same happens to the GDP ratio of the primary balance.

9 The share of the industrial and constructions sector on total GDP at current prices hovered around 35 per cent for the whole period 1952-86. Its contribution to real GDP growth decreased from 50-55 per cent in 1952-74 to ca. 33 per cent in the late 1980s (Prados de la Escosura 2003, pp. 203-205). We prefer the industrial production index reported by INE (Instituto Nacional de Estadística) and international organizations such as the IMF (see Appendix for details) to the historical series of real GDP and industrial production reconstructed by Prados de la Escosura since the former was observable by the government and economic agents, and is also comparable with industrial production indices of other European countries reported by the IMF. 


\subsection{SVAR}

We distinguish two types of structural shocks to identify the two functions, impact and reaction. The first is a shock to the 'impact' equation (2), determining how output (aggregate supply and non-fiscal aggregate demand) responds to the fiscal variable $\left(u_{y}\right)$. The second is a shock to the reaction function (1), shifting the response of the fiscal variable to output $\left(u_{g}\right)$. We observe reduced form shocks $\left(e_{i t}\right)$ to the fiscal variable and output from which the structural shocks are then derived.

In a two variable model consisting of the change in government spending $g$ and the change in industrial output $y$, the reduced-form VAR can be represented as

$\left[\begin{array}{l}g_{t} \\ y_{t}\end{array}\right]=\left[\begin{array}{ll}A_{11}(L) & A_{12}(L) \\ A_{21}(L) & A_{22}(L)\end{array}\right]\left[\begin{array}{l}g_{t-1} \\ y_{t-1}\end{array}\right]+\left[\begin{array}{l}e_{g t} \\ e_{y t}\end{array}\right]$

where $A_{i j}(L)$ is the autoregressive lag polynomial, and $e_{g t}$ and $e_{y t}$, the reduced form shocks, are linear combinations of the structural shocks $u_{t}$. The structural form of model (3) can be expressed as

$\left[\begin{array}{l}g_{t} \\ y_{t}\end{array}\right]=\left[\begin{array}{ll}B_{11}(L) & B_{12}(L) \\ B_{21}(L) & B_{22}(L)\end{array}\right]\left[\begin{array}{l}u_{g t} \\ u_{y t}\end{array}\right]$

Given a linear relationship between the observable and the structural residuals, $e_{t}=C u_{t}$, the structural shocks $u_{t}$ can be identified by first estimating the reduced form VAR and then transforming $e_{g t}, e_{y t .}$.

A correct identification of these relations requires one additional restriction on the matrix $C$, apart from the three short-run restrictions that structural innovations $u_{i t}$ are orthonormal. For reasons stated above, we adopt the long-run restriction of Blanchard and Quah (1989) imposing that there is no long-run influence of pure innovations in the fiscal variable $\left(g_{t}\right)$ on aggregate demand or output growth $\left(y_{t}\right)$. It follows that we can rewrite the reduced form innovations as:

$\left[\begin{array}{l}e_{g t} \\ e_{y t}\end{array}\right]=\left[\begin{array}{cc}c(1) & c(2) \\ 0 & c(3)\end{array}\right]\left[\begin{array}{l}u_{g t} \\ u_{y t}\end{array}\right]$

Coefficients $c(\mathrm{i})$ of matrix $C$ represent the long-run response pattern of the variables to these two structural shocks. In particular $c(2)$ represents the long-run cumulative response of the government spending to a $u_{y}$ shock. A positive coefficient $c(2)$ indicates 
a pro-cyclical fiscal reaction function, as an unanticipated boost to aggregate demand is matched by an increase in government expenditure. Alternatively, a negative coefficient denotes counter-cyclical behaviour of fiscal policy.

Table 1 shows the estimates of the coefficients for the $\operatorname{SVAR}(g, y)$ before and after the transition to democracy. Consistently with our narrative, we find that parameter $c(2)$ is positive and significant at the 5 per cent level in the pre-democratic era, denoting procyclicality, but turns counter-cyclical during the democratic period (negative and significant at 1 per cent level).

\section{<Table 1 here>}

As a robustness check, we repeat the analysis using quarterly data for government expenditures and industrial production, available for the former only from 1962 (see Appendix). Results based on this shorter but larger sample confirm the transition in the sign of the spending reaction function. Estimates of the SVAR for different sub periods of the democratic era - before and after 1989, when Spain joined the EMS - suggests that the government's counter-cyclical response intensified in the later period. This evidence confirms that the loss of discretion in the use of monetary policy led to a more energetic use of fiscal policy by governments, in line with what Galí and Perotti (2003, pp. 17-18) find for all EMU countries in the post-Maastricht period.

In order further to explore the hypothesis of a change in cyclical response, we estimate the SVAR and the reaction function parameter recursively. Figure 2 reveals the transition in the government's spending response from pro- to counter-cyclical. The sudden loss of significance from the late 1960s to the early 1970s coincides chronologically with the process of modernization of fiscal policy identified in our narrative, but the new counter-cyclical regime can only be significantly identified after 1975, and is further reinforced after 1989.

\section{$<$ Figure 2 here $>$}

In principle there exists the possibility that the automatic counter-cyclical properties of the tax function could offset any pro-cyclical spending decision. Testing this hypothesis requires an extension of the model to include tax revenues as an additional variable in a $\operatorname{SVAR}(g, T, y)$. Formally, three long-run additional restrictions are required to identify a system with a tax reaction function as well as the aggregate demand and the 
government spending functions. We assume that spending decisions come first, and only afterwards do tax revenues follow them, that is to say, there is no long-run effect on government spending of a shock to tax revenues $u_{T}$. Also, the equivalent Blanchard and Quah (1989) long-run restriction implies in this case that there is no long-run effect on output growth of either spending or tax revenues shocks.

After imposing the restrictions, the relationship between the observed and the structural residuals becomes:

$$
\left(\begin{array}{l}
e_{g} \\
e_{T} \\
e_{y}
\end{array}\right)=\left(\begin{array}{ccc}
c(1) & 0 & c(4) \\
c(2) & c(3) & c(5) \\
0 & 0 & c(6)
\end{array}\right)\left(\begin{array}{l}
u_{g} \\
u_{T} \\
u_{y}
\end{array}\right)
$$

where $c(2)$ measures the response of tax revenues to government spending shock $u_{g}$; a negative $c(4)$ parameter, representing the long-run response of $g$ to a $u_{y}$ shock, indicates a counter-cyclical spending reaction function; and $c(5)$ describes the response of tax revenues to an output $u_{y}$ shock. ${ }^{10}$ Table 2 confirms the previous results: primary spending reacts pro-cyclically before the mid 1970s and counter-cyclically afterwards. The positive and significant $c(5)$ parameter is consistent with a counter-cyclical contribution of the revenue side of the fiscal reaction function, though we cannot tell whether it is 'automatic' or discretionary policy. ${ }^{11}$

\section{<Table 2 here>}

We finally examine the role played by the 'aggressiveness' of fiscal policy. Our objective is to test whether and to what extent discretionary fiscal shocks $\left(u_{g}\right)$ derived from the SVAR contributed to the volatility of the output process. For this purpose we estimate recursively the percentage of the variance of industrial production due to the structural fiscal shocks. As shown in Figure 3, the contribution of both spending and tax shocks to output volatility was at a maximum in the 1960s and declined significantly from the mid 1970s. Nevertheless, it became more pronounced in the late 1990s, probably due to fiscal adjustment necessary to qualify for the EMU.

10 As Kaminsky et al. (2004) note, only if a negative $c(5)$ parameter is obtained can a pro-cyclical discretionary tax policy be identified. A positive coefficient is unable to discriminate between pro- or counter-cyclical behaviour. So we need only find that $c(5)$ is not negative after 1976 to corroborate the hypothesis of counter-cyclicality under democracy.

11 As a robustness check, we also estimate the reaction function under the alternative specification, that is, assuming that revenues decisions come first, which formally implies imposing $c(2)=0)$. Results do not change. They are not reported in order to save space but are available upon request. 


\section{$<$ Figure 3 here $>$}

Figure 3 suggests that fiscal (and especially spending) shocks were a significant determinant of growth volatility during the autocratic period.

\subsection{An alternative approach: IV}

If the SVAR is not correctly specified the results may be misleading (Rigobon 2004; Jaimovich and Panizza 2007). ${ }^{12}$ Therefore we test the robustness of our findings with the alternative identification method of instrumental variables (IV) (Galí and Perotti 2003; Alesina et al. 2008). We then extend the IV approach to explore more precisely the timing of the observed shift in reaction function.

In order to do this, we re-specify the reaction function as:

$g_{t}=\mathrm{c}+\alpha y_{t}+\beta \mathrm{R} y_{t}+u_{g}$

where $g$ is the growth rate of (log) real primary spending (net of unemployment benefits), $\mathrm{R}$ is a dummy capturing a change in the fiscal policy regime, $y$ is the growth rate of (log) industrial production; and $u_{g}=\Sigma \rho_{\mathrm{i}} u_{t-i}+\varepsilon_{t}$. Parameter $\alpha$ is the elasticity of spending to output and $\alpha>0$ denotes a pro-cyclical reaction function. Parameter $\beta$ is a measure of the impact of a new fiscal policy regime on the spending response to output. $\beta<0$ indicates that the new regime reduces the pro-cyclicality of spending. Finally, residuals $\varepsilon$ are white-noise innovations that are orthogonal to the state of the economy and determine the overall volatility of the fiscal stance. Again, they measure the aggressiveness of discretionary fiscal policy.

A desirable feature of this approach is that it allows us to estimate fiscal shocks adjusted to shifting reaction functions for the whole period 1950-1998. To address potential endogeneity between spending and output, we estimate equation (7) by GMM and use the contemporaneous and lagged growth rate of industrial output in core European

12 Rigobon (2004) demonstrates that, assuming two countries with the same pro-cyclical fiscal policy and standard Keynesian effects on output but different types of shocks, OLS estimates would lead to observe a pro-cyclical fiscal policy in the country where fiscal shocks dominate on output shocks. 
economies as instruments for domestic output. ${ }^{13}$ Benchmark results are presented in Table 3.

\section{<Table 3 here>}

Since our initial interest was whether there was a change in the cyclical fiscal stance of the government across political regimes, we first introduce a 'democracy' dummy, taking the value of 1 after the conclusion of the democratic transition in 1976. Again we find that democratic governments brought in a significant fall in pro-cyclicality (column 1). However, our narrative reveals that institutional as well as political regime changes could have determined the policy shift to counter-cyclicality. Therefore we test a set of additional dummies to capture the impact of a variety of possibly relevant factors. These include: the reforms that followed to the stabilisation plan (taking value 1 after 1960), budget reforms such as the adoption of annual budgeting and the creation of countercyclical funds (1 after 1972), constraints on governments' fiscal behaviour created by Spain's accession to EEC (1 after 1986) and the peseta's entry into the Exchange Rate Mechanism of the EMS (1 after 1989). In principle, the two last events should have 'tied' the hands of the Spanish governments, thus reducing their scope for countercyclical discretionary fiscal policy. On the other hand, a government losing discretionary monetary policy may make increasing use of fiscal policy for stabilisation purposes.

Consistent with the narrative and the previous SVAR findings, our results suggest that the fiscal policy reforms introduced by the pre-democratic regime in the early 1970s and not only the transition from autocracy to democracy - proved critical to reduce fiscal pro-cyclicality (column 3). In fact, joining the EMS in 1989, rather than the accession to EEC, apparently accounts for most of the transition to countercyclical behaviour observed under the democratic regime (columns 4 and 5). Including a double countercyclical shift in the early 1970s and at the end of the 1980s yields consistent results and maximizes the explanatory power of our specification (column 6).

\footnotetext{
13 A similar approach is adopted by Jaimovich and Panizza (2007). Our instrumental variable is a weighted industrial production index of five 'core' European economies (France, West Germany, the Netherlands, Belgium and the UK). The first stage regression has good explanatory power $\left(\mathrm{R}^{2} 0.47\right)$ with coefficients and t-stats: $0.622\left(2.56^{* *}\right)$ and $0.768\left(4.01^{* * *}\right)$ of contemporaneous and lagged foreign output growth, respectively. Unit root tests confirm that the series are stationary. Autoregressive lags are selected on the base of standard (Akaike and Schwartz) criteria.
} 
The economic significance of these reaction functions can be shown with column 6 Table 3, which implies that a 10 percent upswing in industry production prior to 1971 was associated with a 5 percent rise in government spending. Between 1971 and 1989 policy was hardly cyclically responsive at all, while after 1989 to 10 percent upswing in industry production was linked with a 15 percent fall in government spending.

\subsection{Robustness checks}

We now run a series of robustness checks. Since social spending was a key aspect of the social compact agreements negotiated by democratic governments, we test whether this expenditure significantly affected the observed transition to countercyclical fiscal policy. Additionally we analyze the cyclical behaviour of different components of government spending. Results presented in Table 4 suggest that no transition to countercyclicality could be observed in aggregate primary spending (including social security) until the late 1980s (column 7). This is not surprising since structural rather than cyclical objectives (i.e. reducing the gap in social insurance accumulated by Spanish citizens relative to Western European standards) motivated the progression of social spending during the first decade of democracy. All categories of spending, with the exception of social security spending, show the expected negative signs after the two identified transitions to counter-cyclicality (columns 8-12). However, the estimated parameters are statistically significant only for government current and capital transfers (which include subsidies to the industrial sector) from the early 1970s, and government investment and social security spending from the late 1980s. These results suggest that the transition to counter-cyclicality was not identical across spending categories; in particular, government consumption (purchases and wages) seem to have remained procyclical over the period.

\section{<Table 4 here>}

As a further check, we ask whether our results are driven by the specific indicator we have chosen (industrial output) to capture the state of the economy. We therefore use as an alternative measure the growth rate of real GDP. As already noted, official annual GDP estimates became available only in the 1960s and for the previous period have been reconstructed by Prados de la Escosura (2003). The results of Table 5 confirm our main results. Real primary spending (excluding social security) was strongly procyclical under the pre-democratic regime but exhibited a double transition to counter- 
cyclicality in the early 1970s and late 1980s (column 13). We find similar results for real primary spending including social security (column 14): the signs are correct, although the estimated parameters are significant only at the $15 \%$ level of confidence. The evidence for individual spending categories (columns 15-19) is consistent with results already presented in Table 4.

\section{<Table 5 here>}

Finally, we test the robustness of our results to the use of quarterly data. Table 6 (columns 20) confirms the identification of a double countercyclical shift in fiscal policy. Even if we assume a backward looking behaviour, in which governments, given the inertia and complexity of fiscal policy-making, responded to lagged fluctuations of the economy, the results still hold (column 21). Additionally, we test the hypothesis of fiscal policy being constrained by the level of outstanding government debt. In order to do so, we control for the lag of debt-GDP ratio in equation (7), which then becomes the reduced form of a structural model of the determination of government expenditure in which policymakers tend to stabilize the debt/GDP ratio around a target (Galí and Perotti 2003). In fact, we find evidence in favour of debt-constrained spending policy, but again the double shift to counter-cyclicality is confirmed (column 22). The same holds if we introduce election year dummies, which capture possible political budget cycles. Indeed we find evidence of regular political effects in fiscal policy, whose magnitude was especially relevant in the run-up to the general elections of 1979 and 1989 (column 23). These results suggest that spending decisions were in part politicallydriven and are consistent with the hypothesis of political budget cycles in the consolidation of "young" democracies. ${ }^{14}$

\section{$<$ Table 6 here $>$}

\section{Conclusion}

The Spanish experience between 1950 and 1998 provides a case of transition in the cyclical behaviour of fiscal policy. The narrative of Section 1 suggests that, during much of autocratic period the government failed to resist pressures to increase spending

14 Election year dummies are specified as 1 in the four quarters prior to a general election (including the quarter in which the election took place). We test for political budget cycles only using quarterly data because most Spanish elections were held in the first half of the year, so that an annual dummy would capture both pre- and post-election fiscal shocks. An additional problem with annual dummies is the limited number of observations and the absence of sufficient degrees of freedom. 
and nominal wages in economic expansions. Moreover, inadequate fiscal institutions made it virtually impossible for governments to react appropriately to changes in economic conditions. As a consequence, fiscal policy had a clear pro-cyclical bias (as Alesina et al (2008) predict under 'corrupt democracies'). Qualitative evidence of fiscal stance during the boom-and-bust cycles of 1955-59 and 1961-66 supports this conclusion. However, modernization of fiscal institutions and a more disciplined management of social bargaining emerged in the last years of the autocratic regime.

The transition to democracy introduced institutions to govern distributional conflicts. Reforms also increased the built-in countercyclical characteristics of the fiscal regime. This may explain the contradiction with Lane's (2003) and Alesina et al's (2008) predictions; political bargaining became less fragmented and_opportunistic with the end of Spanish autocracy. Under democracy the adoption of centralized tripartite social bargaining created the conditions for the coordination of monetary, fiscal and income policies. Alternatively there was a learning process - perhaps shared with OECD countries - about managing and financing government spending in an era when demands on the state were greatly increased. Modernization of fiscal institutions enhanced both the automatic stabilizing properties of the budget and the government's ability to adjust discretionary fiscal policy to economic fluctuations. Yet until the mid 1980s fiscal policy was determined by structural (rather than cyclical) factors, such as the rapid expansion of social protection and the use of the budget to smooth the consequences of structural adjustment of the industrial sector.

In Section 3 our SVAR detects a transition of the fiscal reaction function from procyclicality under the pre-democratic regime towards counter-cyclicality under democracy, reinforced from the late 1980s. These results hold both for annual and quarterly data, and are confirmed by our IV approach. But the initial transition away from pro-cyclicality is more associated with budgetary reforms of the early 1970s, during the last period of the pre-democratic regime, than with institutions created during the early years of democracy. Subsequently, the reinforcing impact of ERM accession on the countercyclical stance of Spanish fiscal policy is confirmed. The identification of a double transition to countercyclical fiscal policy is robust to different specifications both of the government expenditures variable and the indicator of the state of the economy. An analysis by different spending components suggests that government 
transfers (subsidies) and investment were the main drivers of the observed shift to counter-cyclicality.

Regime change, as measured by PolityIV or the Heinisz index, from autocracy to democracy, and emphasised as critical for the cyclicality of fiscal policy by Lane (2003) and Alesina et al (2008) is not precisely associated for Spain. Rather, the economic policy of regimes appeared to evolve largely independently of political categorisation -

perhaps through a learning and imitation process similar to that of other western European countries. This suggests a more nuanced approach to political economy will better fit the facts of fiscal policy cyclicality

\section{APPENDIX: Data and sources}

\section{Fiscal variables}

Annual

Estadísticas Históricas de España. Siglos XIX-XX, A. Carreras, X. Tafunell, eds. (Fundación BBVA, 2005), c. 12, F. Comín, D. Diaz, "Sector público administrativo y estado del bienestar", vol. II, pp. 873-964

\section{Central government tax revenues:}

1950-61, Table 12.16 "Ingresos del Estado: clasificación económica", p. 940 [includes: indirect and direct tax revenue, monopolies, other current revenue (transfers among public administrations and other current transfers), capital tax revenues].

1962-98, Table 12.21 "Estado: ingresos corrientes y de capital (movimiento de caja), clasificación económica", p. 948 [includes: indirect and direct tax revenue, current and capital transfers, interest revenue, dividends and other]. This series corresponds to the data reported in IMF International Financial Statistics, "Total revenue and grants", ifs:s18481y.zf.

Central government expenditures:

1950-61, Table 12.17 “Gastos del Estado: clasificación económica”, p. 943.

1962-98, Table 12.22 "Estado: gastos corrientes y de capital (movimiento de caja), clasificación económica", p. 949 [includes wages, purchases, current and capital transfers, investment, interest payments, other expenditures]. This series corresponds 
(with minor discrepancies) to the data reported in IMF International Financial Statistics, "Expenditures" (net of lending and repayments), ifs:s18482zfa.

Social security: 1958-98, Table 12.31 “Cuentas de la Seguridad Social”, pp. 958-59

Government debt: 1950-98, Table 12.34 “Deuda pública en circulación”, pp. 962-63.

Quarterly

IMF International Financial Statistics

Central government tax revenues (1962Q1-1998Q4): ifs: s18481zfq

Central government expenditures (1962Q1-1998Q4): ifs: s18482zfq

Government debt (1958Q3-1998Q4): ifs: s18488zfq

\section{Wholesale Price Index}

$\underline{\text { Annual }}$

IMF International Financial Statistics (1950-1998): ifs: s18463zf

Quarterly

IMF International Financial Statistics (1959Q1-1998Q4): ifs: s18463zfq

\section{Industrial Production Index}

Annual

Spain (1950-1998): Estadísticas Históricas de España. Siglos XIX-XX, A. Carreras, X. Tafunell, eds. (Fundación BBVA, 2005), c. 5, A. Carreras, "Industria", vol. I, pp. 357964, Table 5.11 "Índices de la producción industrial", Series INE (Instituto Nacional de Estadística). This series tracks (with minor discrepancies) the industrial production index (s.a.) reported from 1960 by IMF International Financial Statistics, ifs: s18466czfa.

France, Germany, the Netherlands, Belgium and UK (1950-1998): IMF International Financial Statistics, ifs: s13266czf, s13466czf, s13866czf, s12466bzf, s11266czf, respectively.

Quarterly

Spain: IMF International Financial Statistics (1961Q1-1998Q4): ifs: s18466czfq

France, Germany, the Netherlands, Belgium and UK (1957Q1-1998Q4): IMF International Financial Statistics, s13266czfq, s13466czfq, s13866czfq, s12466bzfq, s11266czfq, respectively.

\section{GDP}

Annual

Spain (1950-1998): Prados de la Escosura L. (2003).

France, Germany, the Netherlands, Belgium and UK (1950-1998): The Conference Board Total Economy Database, http://www.conference-board.org/data/economydatabase/ 


\section{SOURCES}

EIU $=$ The Economist Intelligence Unit, Quarterly Economic Reviews: Spain OECD = OECD Economic Surveys: Spain 


\section{BIBLIOGRAPHICAL REFERENCES}

Alberola, E., González-Mínguez, J.M., Hernández De Cos, P., Marqués, J.M. (2003), How cyclical do cyclically-adjusted balances remain? An EU study, Hacienda Pública Española/Revista de Economía Pública, 166, n. 3, pp. 151-181

Alesina, A., Campante F.R., Tabellini, G. (2008), Why is fiscal policy often procyclical?, Journal of the European Economic Association, 6(5), pp. 1006-1036

Andrés, J., Domenech, R., Fatas, A. (2008), The stabilizing role of government size, Journal of Economic Dynamics and Control, 32, n. 2, pp. 571-593

Argimón, I., Gómez Ángel, L., Hernández De Cos, P., Martí, F. (1999), El sector de las administraciones publicas en España, Estudios Económicos, Banco de España, n. 68

Bajo-Rubio, O., Diaz-Roldan, C Esteve, V. (2010) The sustainability of government deficits in Spain 1850-2000 Journal of Applied Economics 13, 2, pp. 263-81

Barro, R. J. (1997) Determinants of Economic Growth: A Cross-Country Study

Battilossi, S., Foreman-Peck, J and Kling, G. (2010) 'Business Cycles and Economic Policy, 1945-2007' in S Broadberry and K H O'Rourke eds. Cambridge Economic History of Modern Europe vol 2: 1870 to the Present, Cambridge University Press

Beltrán, L., Oliart, A. (1967), Gasto Público en España. Madrid

Blanchard, O.J., Quah, D. (1989), The dynamic effects of aggregate demand and supply disturbances, American Economic Review, 79, n. 4, pp. 655-673

Boltho, A. and Toniolo, G (1999) The Assessment: The Twentieth Century-Achievements, Failures, Lessons, Oxford Review of Economic Policy, 15, 4, pp. 1-17

Brender, A., Drazen, A. (2005), Political budget cycles in new versus established democracies, Journal of Monetary Economics, 52, n. 7, 1271-1295

Brender A., Drazen A. (2007), Why is economic policy different in new democracies? Affecting attitudes about democracy, NBER Working Paper n. 13457

Canseco Canseco, J.E. (1978), Política fiscal de España: estudio de la política económica pública española desde el plan de estabilización. Madrid, Instituto de Estudios Fiscales

Carreras , A., Tafunell, X. (2004), Historia económica de la España contemporánea. Barcelona: Crítica

Chang H-C, Huang B-N and Yang C W (2011) Military Expenditure and Economic Growth across Different Groups: A Dynamic Panel Granger-Causality Approach, Economic Modelling, 28, 6, 2416-23

Comín, F. (2007), Reaching a political consensus: The Moncloa Pacts, joining the European Union, and the rest of the journey, in J. Martinez-Vazquez, J.F. Sanz-Sanz (eds.), Fiscal Reform in Spain. Accomplishments and Challenges. Cheltenham: Edward Elgar, pp. 8-58 
Daban, T., Detragiache E., di Bella G., Millesi-Ferretti G.M. and Symansky, S. (2003)

Rules-Based Fiscal Policy in France, Germany, Italy and Spain, IMF Occasional Paper 225

Darby J., Melitz J. (2008), Social spending and automatic stabilizers in the OECD, Economic Policy, 23 (56), pp. 715-756

De Castro, F. (2006), The macroeconomic effects of fiscal policy in Spain, Applied Economics 38, pp. 913-924.

De Castro, F; Hernandez De Cos, P. (2008) The Economic Effects of Fiscal Policy: The Case of Spain, Journal of Macroeconomics, 30, 3, pp. 1005-28

Diallo O. (2009), Tortuous road toward countercyclical fiscal policy: lessons from democratized sub-Saharian Africa, Journal of Policy Modeling, 31, pp. 36-50

Dolado J.J., Sebastián M., Vallés J. (1993), Cyclical patterns of the Spanish economy, Investigaciones Económicas, 17 (3): 445-473

Dow J C R (1964) The Management of the British Economy 1945-1960, Cambridge University Press

Encarnación O. (1997), Social concertation in democratic and market transitions: comparative lessons from Spain, Comparative Political Studies, 20 (4 ), pp. 387-419

Encarnación O. (2001), Labor and pacted democracy: post-Franco Spain in comparative perspective, Comparative Politics, 33 (3), pp. 337-55.

Escario, R., Sabaté, M. and Gadea, M.D. (2011): "La sombra monetaria del déficit en la España de la peseta" / "Monetary Shadow of Deficit. Spain 1874-1998", Investigaciones de Historia Económica 19, 151-181. Revista de la Asociación Española de Historia Económica.

Escario, R., Gadea, M.D. and Sabaté, M. (2012): "Multicointegration, Seigniorage and Fiscal Sustainability. Spain 1857-2000”, Journal of Policy Modeling 34 (2), 270-283.

Fatás, A., Mihov I. (2001), 'Government size and automatic stabilizers: international and intranational evidence', Journal of International Economics, 55, p. 3-28

Fatás, A, Mihov, I. (2003), The case for restricting fiscal policy discretion, The Quarterly Journal of Economics. 118 (4), pp. 1419-1447

Fatás, A., Mihov, I. (2008), Fiscal discipline, volatility and growth, in T. Irwin, G. Perry, L. Servén, R. Suescún (eds.), Fiscal Policy, Stabilization and Growth. Prudence or Abstinence? Washington: World Bank, pp. 43-74

Fatás, A., Mihov, I. (2009), The Euro and fiscal policy, NBER Working paper, n. 14722

Friedman, M. (1997) John Maynard Keynes, Federal Reserve Bank of Richmond Economic Quarterly, Spring 83, 2, pp. 1-23

Fuentes Quintana, E. (1990), Las Reformas Tributarias en España. Barcelona, Crítica

Galí, J. (1994), 'Government size and macroeconomic stability', European Economic Review, 38, 117-132

Galí, J., Perotti, R. (2003). Fiscal policy and monetary integration in Europe, Economic Policy, 18, pp. 533-572 
Galy, M., Pastor, G., Pujol, T. (1993), Spain: Converging with the European Community. Washington: IMF

García Delgado, J.L. (1982), ed., Economía Española: 1960-1980. Madrid: Blume

Gavin M., Hausmann R., Perotti R., Talvi E. (1996), Managing fiscal policy in Latin America and the Caribbean: volatility, procyclicality and creditworthiness, InterAmerican Development Bank, RES Working Paper n. 4032

Gómez Giménez, A. L. (1993), Indicadores de la política fiscal: una aplicación al caso español, Documento de Trabajo n. 9304, Servicio de Estudios, Banco de España

Gómez Giménez, A. L, Roldan Alegre, J. M. (1995), Análisis de la política fiscal en España con una perspectiva macroeconómica (1988-1994), Banco de España, Estudios Económicos, n. 53

González Páramo, J. M. (1990), Tres lustros de cambios estructurales en el sector público, en J.L. García Delgado, ed., Economía Española de la Transición y la Democracia. Madrid: CIS, pp. 245-271

Henisz W (2000) The institutional environment for economic growth Economics and Politics, 12 , pp. 1-31

Jaimovich D., Panizza U. (2007), Procyclicality or reverse causality?, Inter-American Development Bank, Working Paper n. 599

Kaminsky, G., Reinhart, C., Végh, C. (2004), When it rains it pours: procyclical capital flows and macroeconomic policies, in M. Gertler, K. Rogoff, eds., NBER

Macroeconomic Annual 2004. Harvard, Mass: MIT Press

Lane, P. R. (2003), The cyclical behavior of fiscal policy: evidence from the OECD, Journal of Public Economics, 87, 12, pp. 2661-2675

Lane, P.R., Tornell, A. (1996), Power, growth and the voracity effect, Journal of Economic Growth, 1, pp. 213-241

Ledesma Rodríguez, F., Navarro-Ibáñez, M., Pérez Rodríguez, J., Sosvilla Rivero, S. (2005), Implicit regimes for the Spanish peseta/Deutschmark exchange rate, Fedea Documentos de Trabajo, n. 2005-21

Lundberg, E. (1968) Instability and Economic Growth, New Haven and London Yale University Press

Maddison A (1991) Phases of Capitalist Development Oxford University Press

Marín, J. (1996), Efectos estabilizadores de la política fiscal, Estudios Económicos, n. 58, Servicio de Estudios, Banco de España

Martínez-Vázquez, J., Sanz-Sanz J. F. (1990), eds., Fiscal Reform in Spain. Accomplishments and Challenges. Cheltenham: Edward Elgar

Mohanty, M.S., Zampolli, F. (2009), Government size and macroeconomic stability, BIS Quarterly Review, (December,) pp. 55-68

Mohr, M., Morris, R. (2007), Uncertainty in measuring the underlying budgetary position and fiscal stance, Paper presented at the Directorate General for Economic and financial Affairs 2008 workshop "Achieving \& safeguarding sound fiscal positions", European Commission, Brussels 
Perotti, R. (2005), Estimating the effects of fiscal policy in OECD countries, Proceedings, Federal Reserve Bank of San Francisco, March

Prados de la Escosura, L. (2003). El Progreso Económico de España (1850-2000). Bilbao: Fundación BBVA

Prados de la Escosura L., Rosés J., Sanz-Villaroya I. (2011), Economic reforms and growth in Franco's Spain, Revista de Historia Económica / Journal of Iberian and Latin American Economic History 29 (3)

Reinhart C., Reinhart V. (2008), Capital flow bonanzas: an encompassing view of the past and present, NBER Working Paper n. 14321

Reinhart, C., Rogoff, K. (2004), The modern history of exchange rate arrangements: a reinterpretation, Quarterly Journal of Economics, 119, pp. 1-48, Data Appendix

Rigobon (2004). Comments on Kaminsky, G., Reinhart, C., Végh, C. (2004), When it rains it pours: procyclical capital flows and macroeconomic policies, in M. Gertler, K. Rogoff, eds., NBER Macroeconomic Annual 2004. Harvard, Mass: MIT Press

Rodrik D. (1999), Where did all the growth go? External shocks, social conflict, and growth collapses, Journal of Economic Growth, 4(4), pp 385-412,

Romer C. D., Romer D H (1989) Does Monetary Policy Matter? A New Test in the Spirit of Friedman and Schwartz, NBER Macroeconomics Annual Vol.4, Eds. O. J. Blanchard and S. Fischer, MIT Press

Royo S. (2000), From Social Democracy toe Neoliberalism. The Consequences of Party Hegemony in Spain 1983-1996 (New York: St. Martin's Press)

Royo S. (2001), The collapse of social concertation and the failure of socialist economic policies in Spain, South European Society \& Politics, 6 (1), pp. 27-50

Schwartz, P., González M-J. (1978), Una Historia del Instituto Nacional de Industria (1941-1976). Madrid: Tecnos

Talvi, E., Végh, C. (2005), Tax base variability and procyclicality of fiscal policy, Journal of Development Economics, 78 (1), pp. 156-190

Tornell, A., Lane, P. R. (1999), Voracity and growth, American Economic Review,89, pp. $22-46$

Valle, V. (1990), El gasto público en España, en E. Albi Ibañez, ed., La Hacienda Pública en la Democracia. Barcelona: Ariel, pp. 170-179.

Vázquez Juan, A. (1990), Crisis, cambio y recuperación industrial, en J.L. Garcia Delgado, ed., Economía Española de la Transición y la Democracia. Madrid: CIS, pp. 81-117.

Van den Noord, P. (2000), The size and role of automatic fiscal stabilizers in the 1990s and beyond, OECD Economics Department Working Papers, n. 230

Zapico Goñi E. (1988), Financial Management Reform in Spanish Central Government, EIASM, Maastrich 4 


\section{TABLES}

Table 1

Fiscal reaction functions: bivariate SVAR

Variables: real primary spending, industrial output

\begin{tabular}{lccc}
\hline Cumulative response of: & $\begin{array}{c}c(1) \\
\text { spending to } \\
\text { spending shocks }\end{array}$ & $\begin{array}{c}\mathbf{c}(\mathbf{2}) \\
\text { spending to } \\
\text { output shocks }\end{array}$ & $\begin{array}{c}\mathrm{c}(3) \\
\text { output to } \\
\text { output shocks }\end{array}$ \\
\hline Annual data & $0.050^{* * *}$ & $\mathbf{0 . 0 2 4} * *$ & $0.046^{* * * *}$ \\
1951-1975 & $(0.000)$ & $\mathbf{( 0 . 0 2 5})$ & $(0.000)$ \\
& $0.055^{* * *}$ & $\mathbf{- 0 . 0 4 8} * * *$ & $0.039 * * *$ \\
1976-1988 & $(0.000)$ & $\mathbf{( 0 . 0 0 0 )}$ & $(0.000)$ \\
& & & \\
Quarterly data & $0.032^{* * *}$ & $\mathbf{0 . 0 2 5} * * *$ & $0.023^{* * *}$ \\
1964:II-1975:IV & $(0.000)$ & $\mathbf{( 0 . 0 0 0 )}$ & $(0.000)$ \\
& $0.030^{* * *}$ & $\mathbf{- 0 . 0 1 2} * * *$ & $0.017 * * *$ \\
1976:I-1998:IV & $(0.000)$ & $\mathbf{( 0 . 0 0 0 )}$ & $(0.000)$ \\
& $0.029 * * *$ & $\mathbf{- 0 . 0 0 9} * *$ & $0.015^{* * *}$ \\
1976:I-1989:IV & $(0.000)$ & $\mathbf{( 0 . 0 2 6})$ & $(0.000)$ \\
& $0.009^{* * *}$ & $\mathbf{- 0 . 0 1 9 * * *}$ & $0.026^{* * *}$ \\
1990:I-1998:IV & $(0.000)$ & $\mathbf{( 0 . 0 0 0 )}$ & $(0.000)$ \\
\hline
\end{tabular}

Note. Unit root tests (not reported) confirm that the series are stationary. Annual data with two lags; quarterly data (only available since 1962) with eight lags; autoregressive lags are selected on the basis of Akaike and Schwarz criteria; p-values in parentheses. Substituting real GDP for industrial production, the results for parameter $c(2)$ are as follows: 1950-75 $0.015^{*}(0.093)$, 1976-98 -0.020 (0.110). Data and sources: see Appendix.

\section{Table 2}

Fiscal reaction functions: trivariate SVAR

Variables: real primary spending, tax revenues, industrial output

\begin{tabular}{|c|c|c|c|c|c|c|}
\hline $\begin{array}{l}\text { Cumulative } \\
\text { response } \\
\text { of: }\end{array}$ & $\begin{array}{l}\text { c(1) } \\
\text { spending to } \\
\text { spending } \\
\text { shock }\end{array}$ & $\begin{array}{l}c(2) \\
\text { revenues to } \\
\text { spending } \\
\text { shock }\end{array}$ & $\begin{array}{l}\mathrm{c}(3) \\
\text { revenues to } \\
\text { revenues } \\
\text { shock }\end{array}$ & $\begin{array}{c}\text { c(4) } \\
\text { spending } \\
\text { to } \\
\text { output } \\
\text { shock }\end{array}$ & $\begin{array}{c}\mathrm{c}(5) \\
\text { revenues } \\
\text { to } \\
\text { output } \\
\text { shock }\end{array}$ & $\begin{array}{l}\text { c(6) } \\
\text { output to } \\
\text { output } \\
\text { shock }\end{array}$ \\
\hline $1951-1975$ & $\begin{array}{c}0.048 * * * \\
(0.000)\end{array}$ & $\begin{array}{c}0.018 * * \\
(0.022)\end{array}$ & $\begin{array}{c}0.038 * * * \\
(0.000)\end{array}$ & $\begin{array}{c}0.026 * * \\
(0.010)\end{array}$ & $\begin{array}{c}0.019 * * \\
(0.029)\end{array}$ & $\begin{array}{c}0.048 * * * \\
(0.000)\end{array}$ \\
\hline 1976-1998 & $\begin{array}{c}0.058 * * * \\
(0.000)\end{array}$ & $\begin{array}{l}0.030 * * \\
(0.022)\end{array}$ & $\begin{array}{c}0.060 * * * \\
(0.000)\end{array}$ & $\begin{array}{c}-0.044 * * * \\
(0.001)\end{array}$ & $\begin{array}{l}0.024 * \\
(0.093)\end{array}$ & $\begin{array}{c}0.039 * * * \\
(0.000)\end{array}$ \\
\hline
\end{tabular}

Note. Annual data with two lags, autoregressive lags selected on the base of Akaike and Schwarz criteria; $p$-values in parentheses. Data and sources: see Appendix 


\section{Table 3}

Fiscal reaction function and institutional change: benchmark IV estimates

Dependent variable: $\Delta(\log )$ of real primary spending
(1)
(2)
(3)
(4)
(5)
(6)

\begin{tabular}{|c|c|c|c|c|c|c|c|}
\hline constant & & $\begin{array}{c}0.058 * * * \\
(0.000)\end{array}$ & $\begin{array}{c}0.060 * * * \\
(0.000)\end{array}$ & $\begin{array}{c}0.063 * * * \\
(0.000)\end{array}$ & $\begin{array}{c}0.056^{* * * *} \\
(0.000)\end{array}$ & $\begin{array}{c}0.047 * * * \\
(0.000)\end{array}$ & $\begin{array}{c}0.054 * * * \\
(0.000)\end{array}$ \\
\hline $\begin{array}{l}\Delta(\log ) \\
\text { industrial }\end{array}$ & & $\begin{array}{c}0.388 * * * \\
(0.006)\end{array}$ & $\begin{array}{c}0.483^{* * * *} \\
(0.009)\end{array}$ & $\begin{array}{c}0.464 * * * \\
(0.001)\end{array}$ & $\begin{array}{c}0.404 * * * \\
(0.001)\end{array}$ & $\begin{array}{c}0.470 * * * \\
(0.000)\end{array}$ & $\begin{array}{c}0.510^{* * * *} \\
(0.000)\end{array}$ \\
\hline & $\begin{array}{l}\text { democratic } \\
\text { neocorporatism } \\
\text { (post 1976) }\end{array}$ & $\begin{array}{c}-1.906 * * * \\
(0.000)\end{array}$ & $\begin{array}{c}-1.524 * * * \\
(0.001)\end{array}$ & $\begin{array}{c}-1.064 * * * \\
(0.007)\end{array}$ & $\begin{array}{l}-0.537 \\
(0.300)\end{array}$ & $\begin{array}{c}0.046 \\
(0.903)\end{array}$ & \\
\hline & Stabilization & & -0.094 & & & & \\
\hline & $\begin{array}{l}\text { Plan reforms } \\
\text { (post 1960) }\end{array}$ & & $(0.581)$ & & & & \\
\hline $\begin{array}{l}\text { interacted } \\
\text { with: }\end{array}$ & $\begin{array}{l}\text { budget reforms } \\
\text { (post 1971) }\end{array}$ & & & $\begin{array}{c}-0.675 * * * \\
(0.000)\end{array}$ & & & $\begin{array}{c}-0.472 * * * \\
(0.000)\end{array}$ \\
\hline & EEC & & & & -0.506 & & \\
\hline & $\begin{array}{l}\text { accession } \\
\text { (post 1986) }\end{array}$ & & & & $(0.390)$ & & \\
\hline & ERM & & & & & $-1.507 * * *$ & $-1.481 * * *$ \\
\hline & $\begin{array}{l}\text { accession } \\
\text { (post 1989) }\end{array}$ & & & & & $(0.004)$ & $(0.000)$ \\
\hline J-stat & & 0.139 & 0.176 & 0.156 & 0.151 & 0.155 & 0.142 \\
\hline overid & & 0.038 & 0.016 & 0.026 & 0.029 & 0.026 & 0.035 \\
\hline
\end{tabular}

Note. Annual frequency; 47 observations; sample 1952-98. Two autoregressive lags selected on the basis of Akaike and Schwarz criteria; p-values among parenthesis. GMM estimated with Bartlett kernel, fixed Newey-West bandwith, and prewithening. Instruments are the contemporaneous and lagged growth rate of a weighted industrial production index of 5 European core economies, plus lagged dependent variable and regressors. Data and sources: see Appendix. 
Table 4

Robustness check 1: government spending components

Dependent variable: $\Delta(\log )$ of

\begin{tabular}{|c|c|c|c|c|c|c|c|}
\hline & & $\begin{array}{c}\text { real } \\
\text { primary } \\
\text { spending } \\
\text { (incl. SS) } \\
\text { (7)§ }\end{array}$ & $\begin{array}{l}\text { government } \\
\text { purchases }\end{array}$ & $\begin{array}{l}\text { government } \\
\text { wages }\end{array}$ & $\begin{array}{l}\text { government } \\
\text { investment }\end{array}$ & $\begin{array}{c}\text { government } \\
\text { transfers }\end{array}$ & $\begin{array}{c}\text { social } \\
\text { security } \\
\text { spending } \\
(12) \S\end{array}$ \\
\hline constant & & $\begin{array}{c}0.038 * * * \\
(0.000)\end{array}$ & $\begin{array}{c}0.002 \\
(0.906)\end{array}$ & $\begin{array}{l}-0.017 \\
(0.366)\end{array}$ & $\begin{array}{c}0.022 \\
(0.546)\end{array}$ & $\begin{array}{l}0.110^{* *} \\
(0.044)\end{array}$ & $\begin{array}{c}0.059 * * \\
(0.011)\end{array}$ \\
\hline $\begin{array}{l}\Delta(\log ) \\
\text { industrial } \\
\text { output }\end{array}$ & & $\begin{array}{c}0.756 * * * \\
(0.000)\end{array}$ & $\begin{array}{c}0.741 * * * \\
(0.002)\end{array}$ & $\begin{array}{c}1.214 * * * \\
(0.000)\end{array}$ & $\begin{array}{c}0.922 * * \\
(0.038)\end{array}$ & $\begin{array}{c}2.657 * * \\
(0.030)\end{array}$ & $\begin{array}{l}0.549^{*} \\
(0.096)\end{array}$ \\
\hline \multirow[t]{2}{*}{$\begin{array}{l}\text { interacted } \\
\text { with: }\end{array}$} & $\begin{array}{l}\text { budget } \\
\text { reforms } \\
\text { (post 1971) }\end{array}$ & $\begin{array}{l}-0.298 \\
(0.185)\end{array}$ & $\begin{array}{l}-0.125 \\
(0.644)\end{array}$ & $\begin{array}{l}-0.339 \\
(0.241)\end{array}$ & $\begin{array}{l}-0.251 \\
(0.736)\end{array}$ & $\begin{array}{c}-2.754 * * * \\
(0.010)\end{array}$ & $\begin{array}{c}0.795 \\
(0.435)\end{array}$ \\
\hline & $\begin{array}{l}\text { ERM } \\
\text { accession } \\
\text { (post 1989) }\end{array}$ & $\begin{array}{c}-1.340 * * * \\
(0.000)\end{array}$ & $\begin{array}{l}-0.158 \\
(0.908)\end{array}$ & $\begin{array}{l}-1.840 \\
(0.291)\end{array}$ & $\begin{array}{c}-3.510^{* *} \\
(0.013)\end{array}$ & $\begin{array}{l}-0.098 \\
(0.961)\end{array}$ & $\begin{array}{c}-4-154 * * * \\
(0.000)\end{array}$ \\
\hline J-stat & & 0.107 & 0.092 & 0.163 & 0.085 & 0.051 & 0.035 \\
\hline $\begin{array}{l}\text { overid } \\
p \text {-value }\end{array}$ & & 0.081 & 0.115 & 0.022 & 0.135 & 0.301 & 0.439 \\
\hline
\end{tabular}

Note. See Table 3. § Sample 1961-1998; 38 observations. 
Table 5

Robustness check 2: alternative measure of economic activity

Dependent variable: $\Delta(\log )$ of

\begin{tabular}{|c|c|c|c|c|c|c|c|c|}
\hline & & $\begin{array}{c}\text { real } \\
\text { primary } \\
\text { spending } \\
\text { (13) }\end{array}$ & $\begin{array}{c}\text { real } \\
\text { primary } \\
\text { spending } \\
\text { (incl. SS) } \\
(14) \S\end{array}$ & $\begin{array}{l}\text { government } \\
\text { purchases }\end{array}$ & $\begin{array}{c}\text { government } \\
\text { wages }\end{array}$ & $\begin{array}{l}\text { government } \\
\text { investment }\end{array}$ & $\begin{array}{l}\text { government } \\
\text { transfers }\end{array}$ & $\begin{array}{c}\text { social } \\
\text { security } \\
\text { spending } \\
\\
(19) \S\end{array}$ \\
\hline constant & & $\begin{array}{c}0.052 * * * \\
(0.006)\end{array}$ & $\begin{array}{c}0.064 * * \\
(0.045)\end{array}$ & $\begin{array}{l}-0.047 \\
(0.268)\end{array}$ & $\begin{array}{l}-0.032 \\
(0.248)\end{array}$ & $\begin{array}{l}-0.057 \\
(0.243)\end{array}$ & $\begin{array}{c}0.072 \\
(0.350)\end{array}$ & $\begin{array}{c}0.073 \\
(0.161)\end{array}$ \\
\hline $\begin{array}{l}\Delta(\log ) \text { real } \\
\text { GDP }\end{array}$ & & $\begin{array}{c}0.742 * * \\
(0.012)\end{array}$ & $\begin{array}{c}0.682 \\
(0.159)\end{array}$ & $\begin{array}{l}1.467 * * \\
(0.022)\end{array}$ & $\begin{array}{c}1.712 * * * \\
(0.000)\end{array}$ & $\begin{array}{c}3.755^{* * * *} \\
(0.001)\end{array}$ & $\begin{array}{c}2.072 \\
(0.135)\end{array}$ & $\begin{array}{l}0.976^{*} \\
(0.085)\end{array}$ \\
\hline \multirow[t]{2}{*}{$\begin{array}{l}\text { interacted } \\
\text { with: }\end{array}$} & $\begin{array}{l}\text { budget } \\
\text { reforms } \\
\text { (post 1971) }\end{array}$ & $\begin{array}{c}-0.619 * * \\
(0.019)\end{array}$ & $\begin{array}{l}-0.499 \\
(0.117)\end{array}$ & $\begin{array}{c}0.128 \\
(0.803)\end{array}$ & $\begin{array}{c}-0.865^{* *} \\
(0.022)\end{array}$ & $\begin{array}{l}-1.852 * \\
(0.087)\end{array}$ & $\begin{array}{l}-0.761 \\
(0.378)\end{array}$ & $\begin{array}{c}0.050 \\
(0.957)\end{array}$ \\
\hline & $\begin{array}{l}\text { ERM } \\
\text { accession } \\
\text { (post 1989) }\end{array}$ & $\begin{array}{c}-1.105^{* *} \\
(0.024)\end{array}$ & $\begin{array}{l}-1.812 \\
(0.125)\end{array}$ & $\begin{array}{c}-0.362 \\
(0.742)\end{array}$ & $\begin{array}{c}3.387 \\
(0.132)\end{array}$ & $\begin{array}{l}-2.334 * \\
(0.090)\end{array}$ & $\begin{array}{c}-3.791 * * \\
(0.021)\end{array}$ & $\begin{array}{l}-2.413 \\
(0.147)\end{array}$ \\
\hline J-stat & & 0.073 & 0.089 & 0.052 & 0.054 & 0.058 & 0.060 & 0.054 \\
\hline $\begin{array}{l}\text { overid } \\
\text { p-value }\end{array}$ & & 0.061 & 0.039 & 0.114 & 0.107 & 0.095 & 0.089 & 0.107 \\
\hline
\end{tabular}

Note. See Table 3. § Sample 1961-1998; 38 observations. 
Table 6

Robustness check 3: quarterly data

Dependent variable: $\Delta(\log )$ of real primary spending

\begin{tabular}{|c|c|c|c|c|c|}
\hline & & $(20)$ & (21) & (22) & (23) \\
\hline & & benchmark & $\begin{array}{l}\text { lagged } \\
\text { output }\end{array}$ & $\begin{array}{c}\text { debt } \\
\text { constrained }\end{array}$ & $\begin{array}{c}\text { political } \\
\text { cycles }\end{array}$ \\
\hline \multicolumn{2}{|l|}{ constant } & $\begin{array}{c}0.017 * * * \\
(0.000)\end{array}$ & $\begin{array}{c}0.016^{* * * *} \\
(0.000)\end{array}$ & $\begin{array}{c}0.021 * * * \\
(0.000)\end{array}$ & $\begin{array}{c}0.010^{* * * *} \\
(0.000)\end{array}$ \\
\hline \multirow{3}{*}{$\begin{array}{l}\Delta(\log ) \\
\text { industrial } \\
\text { output } \\
\text { interacted } \\
\text { with: }\end{array}$} & & $\begin{array}{c}0.301 * * * \\
(0.000)\end{array}$ & $\begin{array}{c}0.335^{* * *} * \\
(0.000)\end{array}$ & $\begin{array}{c}0.356^{* * *} \\
(0.000)\end{array}$ & $\begin{array}{c}0.587 * * * \\
(0.000)\end{array}$ \\
\hline & $\begin{array}{l}\text { budget } \\
\text { reforms } \\
\text { (post 1971) }\end{array}$ & $\begin{array}{c}-0.623 * * * \\
(0.000)\end{array}$ & $\begin{array}{c}-0.469 * * * \\
(0.000)\end{array}$ & $\begin{array}{c}-0.651 * * * \\
(0.000)\end{array}$ & $\begin{array}{c}-0.851 * * * \\
(0.000)\end{array}$ \\
\hline & $\begin{array}{l}\text { ERM } \\
\text { accession } \\
\text { (post 1989) }\end{array}$ & $\begin{array}{c}-1.196 \text { *** } \\
(0.000)\end{array}$ & $\begin{array}{c}-1.394 * * * \\
(0.000)\end{array}$ & $\begin{array}{c}-0.426^{* *} \\
(0.020)\end{array}$ & $\begin{array}{c}-0.904 * * * \\
(0.000)\end{array}$ \\
\hline \multirow[t]{3}{*}{$\begin{array}{l}\text { Lagged } \\
\text { debt/GDP }\end{array}$} & & & & $\begin{array}{c}-0.023^{* * *} \\
(0.001)\end{array}$ & \\
\hline & 1977 & & & & $\begin{array}{c}0.008 * * \\
(0.032)\end{array}$ \\
\hline & 1979 & & & & $\begin{array}{c}0.034 * * * \\
(0.000)\end{array}$ \\
\hline \multirow[t]{3}{*}{ Elections: } & 1982 & & & & $\begin{array}{c}0.005 * * \\
(0.018)\end{array}$ \\
\hline & 1986 & & & & $\begin{array}{c}0.010 * * * \\
(0.000)\end{array}$ \\
\hline & 1989 & & & & $\begin{array}{c}0.034 * * * \\
(0.000)\end{array}$ \\
\hline J-stat & & 0.116 & 0.117 & 0.131 & 0.160 \\
\hline overid & & 0.001 & 0.001 & 0.000 & 0.000 \\
\hline
\end{tabular}

p-value

Note. Quarterly frequency; 140 observations; sample 1964:I-1998:IV. Seven autoregressive lags selected on the basis of Akaike and Schwarz criteria; p-values among parenthesis. GMM estimated with Bartlett kernel, fixed Newey-West bandwith, and prewithening. Instruments are the contemporaneous and lagged growth rate of a weighted industrial production index of 5 European core economies, plus lagged dependent variable and regressors. Data and sources: see Appendix. 


\section{FIGURES}

\section{Figure 1}

Transitions in the Spanish fiscal regime

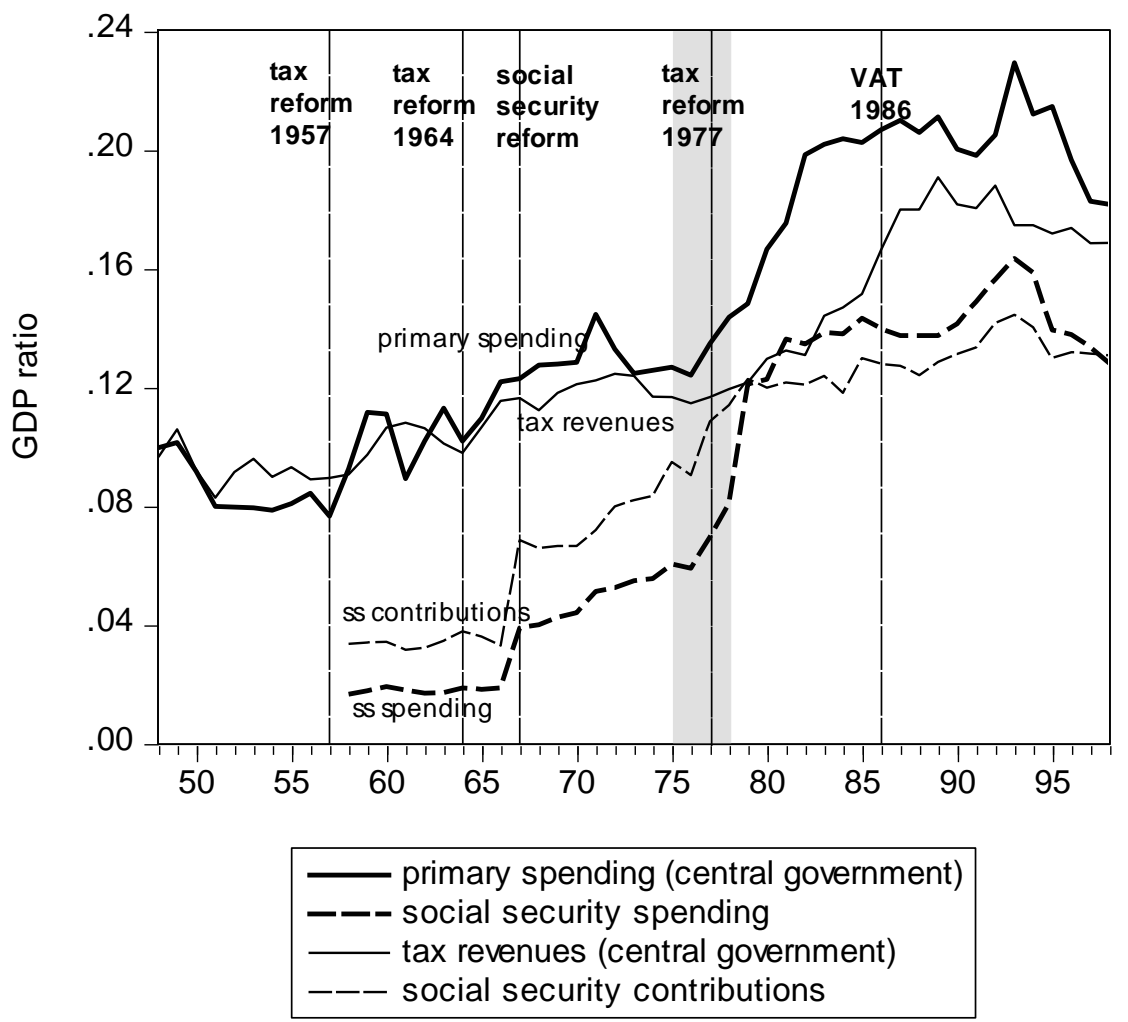

Notes. Democratic transition in grey shadow. Data and sources: see Appendix. 


\section{Figure 2}

Shifting reaction function: SVAR results

Recursive SVAR Estimation of $c(2), 1951-1998$

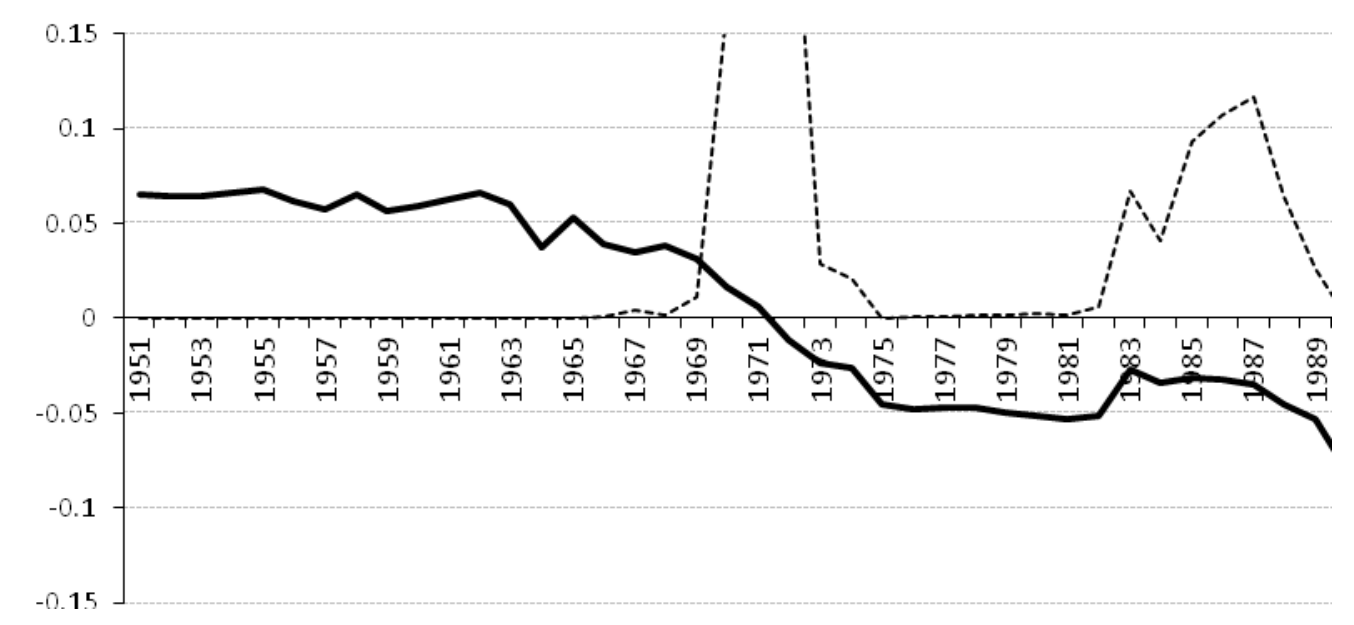

Notes. See Table 2. Recursive estimation starting with the whole sample and gradually focusing in the last years by eliminating the first ones (1951-1998... 1990-1998). Pvalue plotted as dotted line. 


\section{Figure 3}

Recursive estimate of growth (industrial output) variance decomposition

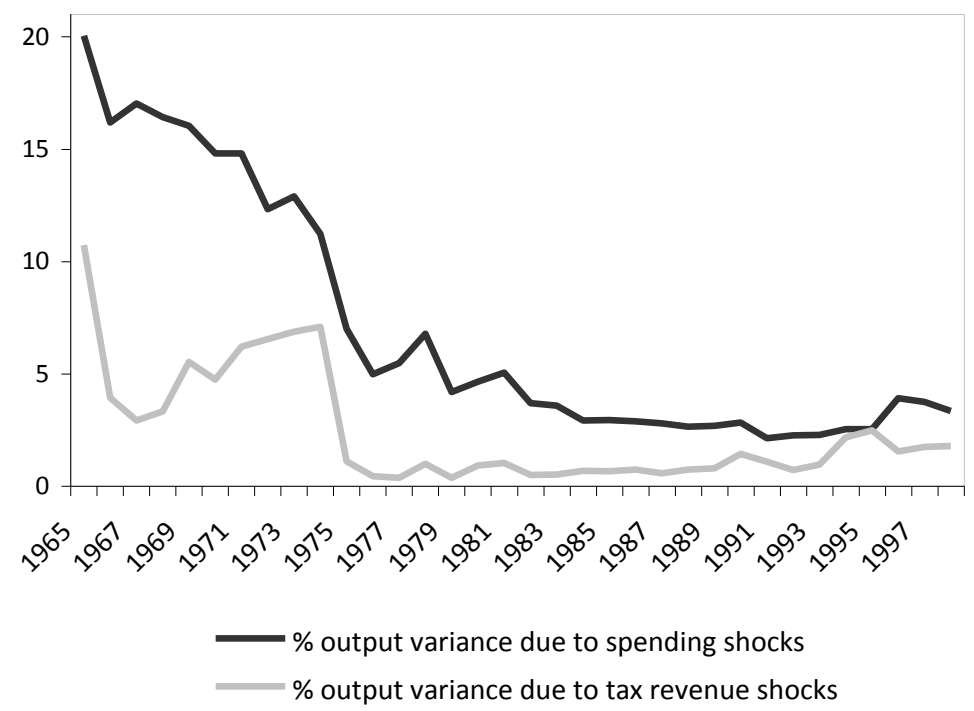

Notes. Recursive estimates based on bivariate SVARs (real primary spending, industrial output) and (real tax revenues, industrial output) with annual data and two lags at a 5-year horizon. A recursive estimate based on trivariate SVAR (real primary spending, real tax revenues, industrial output) gives the same results. 